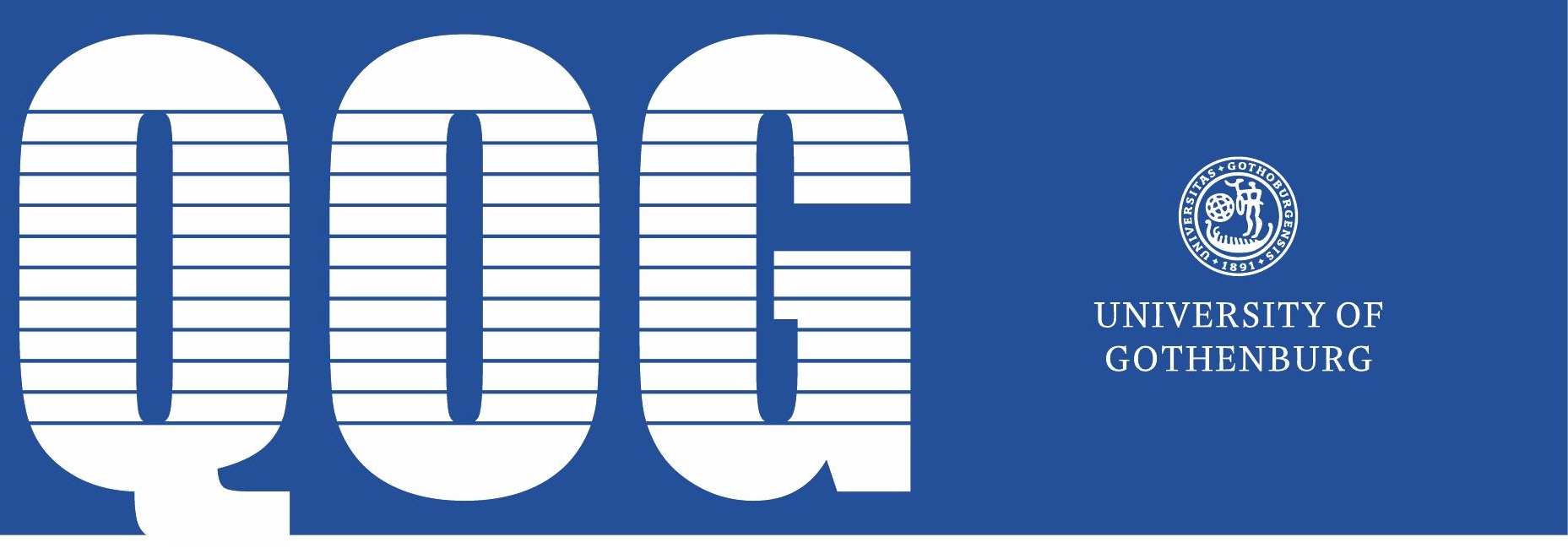

\title{
THE IMPORTANCE OF ELECTORAL AND JUDICIAL TRUST FOR REGIME SUPPORT
}

\author{
STEFAN DAHLBERG
}

SÖREN HOLMBERG

WORKING PAPER SERIES 2015:7

QOG THE QUALITY OF GOVERNMENT INSTITUTE

Department of Political Science

University of Gothenburg

Box 711, SE 40530 GÖTEBORG

April 2015

ISSN 1653-8919

(C) 2015 by Stefan Dahlberg \& Sören Holmberg. All rights reserved. 
The Importance of Electoral and Judicial Trust for Regime Support

Stefan Dahlberg

Sören Holmberg

QoG Working Paper Series 2015:7

April 2015

ISSN 1653-8919

\section{ABSTRACT}

What kind of institutions is most essential to be trustworthy in order for a society to function well? To the extent that previous research has addressed the problem, trust in electoral, judicial, public administration and economic institutions have been most frequently mentioned as most important. The problem, however, is worth a more thorough research approach, where trust in different kind of institutions is systematically compared across political systems. The study is based on five different data sources, three aggregated datasets (CSES, WVS and ESS) and two surveys of Swedish citizens (SOM and the Lore Citizen Panel). When it comes to regime support (and legitimacy) institutional trust matters; especially trust in electoral and judicial institutions. Quality of government matters also. Economic factors, however, matter less in this instance. Political factors rule, not economical. Nations succeed when there is trust in electoral and judicial institutions and when there are impartial public administrations.

\section{Stefan Dahlberg}

The Quality of Government Institute

Department of Political Science

University of Gothenburg

Stefan.dahlberg@pol.gu.se

\section{Sören Holmberg}

The Quality of Government Institute

Department of Political Science

University of Gothenburg

Soren.holmberg@pol.gu.se 
Trust builds societies. Without trust we would not put money in banks, eat at restaurants or leave our children at school. Lacking trust most cities would have surrounding walls like in ancient times and many of us would be carrying arms as in bad old days. Without trust human exchange does not happen easily and civil society runs the risk of breaking down. Trust does not only minimize violence (Schneier 2012). It makes all endeavors more efficient, saves time, and makes everything less expensive. The operating ingredient is that trust lowers transaction costs. In societies with high levels of interpersonal social trust and high levels of institutional trust most things run smoother and at lower costs (Holmberg and Weibull 2013, Norris 2008a, Newton and Norris 2000, Luhman 1989, Trägårdh 2009).

In theory and more generally, all this is well and almost self-evident. But trust it not an either or commodity. With zero trust most things do not work, but what about with some trust or medium trust? In theory as well as operationally, trust must be conceived of as a graded phenomenon, not as a dichotomy. Furthermore, what kind of trust are we talking about? Social trust between people? (Putnam 1993, 2001) Or people's trust in a society's different institutions? (Lipset and Schneider 1983). And if the later, what kind of institutions is most essential to be trustworthy in order for a society to function well? Electoral institutions? Judicial institutions? Civil Society institutions? Economic institutions? Religious institutions? Communicative institutions? Public Administration institutions? Or some other kind of institution?

To the extent that previous research has addressed the problem, trust in electoral, judicial, public administration and economic institutions have been most frequently mentioned as most important (Alesina and La Ferrara 2000, Acemoglu and Robinson 2012, Rothstein 1998); for older times trust in religious institutions as well (Moberg 2011). If any institutions have to be especially mentioned, the best candidates would probably be located within the electoral or judicial systems (Rothstein and Stolle 2008). Trust in the rule of law is often singled out as the cornerstone in any legitimate and rightful commonwealth (Uslaner 2008) and trust in the electoral input side of democracy is usually seen as an indispensable part of a well-functioning democratic regime. The problem, however, is worth a more thorough research approach, where trust in different kind of institutions - and their impact on how well societies are governed - is systematically compared across political systems. That is the quest we have set up to pursue in this article. 


\section{Theoretical Vantage Point}

Our theoretical problem is regime support and the extent to which, and through which mechanisms, popular support is related to peoples' trust in different societal institutions. The hypothesis is that trust matters. And that trust theoretically and out there in the real world is something different and separate from support or positive evaluations.

Trust lowers transaction costs and enhances compliance behavior. What should be done gets done less costly, more efficiently and quicker. And that is more appreciated among people than the opposite, that what is done is done more costly, less efficiently and more slowly. Consequently, trust in important societal institutions is essential for building and preserving support for political regimes. By regime support we mean the degree to which citizens positively evaluate governance outcomes; not only assessments of policies or policy outputs, but judgments of functionalities on the ground.

In this context we will restrict the analysis to democratic regimes. Thus, our concrete focus becomes how citizens in democracies evaluate how their democratic system works and the extent to which these evaluations are associated with trust in different societal institutions. Observe that we are interested in how people assess how their democratic polity functions (works). Whether or not citizens are in favor of a democratic system as such is not our research object.

When it comes to institutional trust and the relationship to regime support and legitimacy, previous research has paid most attention to trust in two specific kinds of institutions - electoral and judicial institutions (Rothstein 1998, 2013, Kumlin 2004, Gilley 2009, Ostrom 2005, Rose-Ackerman 2004, Tyler 2003, Uslaner 2002). We will do the same. But while focusing on electoral and judicial institutions, we will not ignore other societal institutions of possible relevance. The impact of trust in electoral and judicial institutions on democratic regime support will be put in perspective by also studying the effect of trust in other societal institutions. Our theoretical expectation is that trust in especially electoral institutions, but also in judicial institutions, are stronger related to evaluations of how democratic regimes functions, than are trust in other types of societal institutions; whether they are economic institutions, religious institutions, civil society institutions, bureaucratic institutions or media institutions. 
The reason for this hypothesis is twofold. First, electoral institutions for sure, but as well judicial institutions are constitutive elements in a democratic system. If they fail to function there is no democracy. Unfree and unfair elections, and police and judges that do not uphold the law and control corruption are recipes for a dysfunctional democratic system. Rule of elections and rule of law are at the foundation of any functioning democracy.

Second, trust research has showed that institutional trust on the individual level builds on and is sustained by a number of factors, among which peoples' perceptions of how an institution fulfills its main task is the most essential (Holmberg and Weibull 2013, Mayer 1995, Stahl and Sitkin 2004, Luhman 1989, Misztal 1996). Trust is mostly a consequence of the degree to which citizens feel that an institution performs what it is supposed to perform. Job performance is the key. Bad performance causes trust to go down, good performance causes trust to go up.

\section{A Simplified and Operationalized Model}

Ideally and in an empirical fashion, we would like to be able to study good government and the extent to which good government is dependent on - or at least related to - trust in different forms of societal institutions. However, in order to achieve something close to that we have to make simplifications, theoretically as well as operationally. Our study object - our dependent variable ought ideally to be some kind of "objective" measure of how well different political systems perform. In practice, in our case, we have settled for a rather rough proxy variable based on how citizens subjectively assess the performance of their polity. In a way we let people be the judge of whether their political system is run well or not. We have chosen the much discussed and often criticized SWoD-variable as our operational dependent variable (Fuchs, Guidorossi and Svensson 1995, Lagos 2003, Linde and Ekman 2003, Esaiasson and Ottervik 2014). ${ }^{1}$ The acronym stands for Satisfaction with the Working of Democracy. As a subjective measure of "job performance" it has been extensively applied across many countries around the world. And that is a big advantage, since it increases the number of cases in our empirical tests. A potential drawback is that the SWoDindex is multidimensional, measuring short term factors, mainly economic circumstances and gov-

\footnotetext{
${ }^{1}$ In order to emphasize that we are talking about Satisfaction with the Working of Democracy, not Satisfaction with Democracy, we use the acronym SWoD instead of the perhaps sometimes misleading SWD.
} 
ernment performances, as well as more long term factors related to the status of civil rights and the extent of free and fair elections. This drawback does not necessarily constitute a problem in our case, however. We want a broad measure of job performance encompassing short term economic and government assessments as well as more systemic judgments of regime procedures and outcomes. A more evident drawback is that the SWoD-measure is only applicable for democratic political systems. Consequently, our study is restricted to democratic nations, excluding authoritarian and non-democratic countries like China, Vietnam, Cuba and Zimbabwe (Charron and Lapuente 2012).

An advantage of SWoD that surprised us because we did not know it when we started our study is that among our chosen thirty four test countries, the aggregated SWoD measure correlates very highly with another "Good Government" measure - Bruce Gilley's much used measure of state legitimacy. Gilley's theoretical definition is that "a state is legitimate if it holds and exercises political power with legality, justification, and consent" (Gilley 2009: 8). He operationalize legitimacy using a complicated system encompassing no less than nine indicators, most of them involving attitudinal data taken from comparative surveys and aggregated to the national level (pp 14-15). The correlation between Gilley's elaborate legitimacy measure and the more simple and straightforward SWoD measure is . 71 in our sample of countries. This means that in operational terms Gilley's measure of legitimacy and the SWoD measure are, if not scientific siblings so at least close cousins (see also Gjefsen 2012 as well as Esaiasson and Ottervik 2014).

Consequently, in an empirical sense and with a little stretch, our study could not only be seen as a study of the importance of institutional trust for regime support, but as well as a study of the importance of institutional trust for regime legitimacy. However, we will not go down that road any further. Studying regime support is good and tough enough without complicating things by widening the task and include the legitimacy concept as part of our dependent variable.

Our explanatory factor, trust in different kinds of institutions, involve less problematic simplifications. Trust is an inherently subjective individual trait; it can be aggregated to a group level, but it is best measured subjectively on the individual level (Pharr and Putnam 2000). An accessibility problem could be that we - in the present context - do not want to study the impact of the widely measured inter-personal trust phenomenon (Rothstein 1998, La Porta et al. 1999). Instead we want to study the impact of different kinds of institutional trust, and consequently, need measures of 
trust in various sorts of societal institutions, not only the more standard measures of trust in government or parliament. Luckily and mainly thanks to the World Value Survey (WVS), there are today not a shortage of useful comparative measures of institutional trust, covering a wide variety of different institutions (Inglehart 1997). ${ }^{2}$

WVS measures trust in some sixteen different institutions across a large number of countries. All of these sixteen institutions will be part of our analysis but we are especially interested in studying the impact of political and legal institutions. The reason being that previous research has claimed that the functioning of political-legal institutions is of special importance for regime support. Rule of law and the procedural performance and/or output of democratic/political input institutions like parliaments and political parties are essential. The WVS studies encompass trust measures of two legal institutions (Justice System and Police) and of four political institutions (Political Parties, Parliament, Government and United Nations).

Even if our model is simplified - not least in that we specify that institutional trust "causes" SWoD, and not the other way around - we need to include a couple of other explanatory variables in our test in order not to exaggerate the potential impact of the institutional trust factors on the dependent variable - citizens' degree of support/positive evaluation of their democratic regime. Two obvious controls are the state of the economy and the quality of government. We know from previous research that citizens in richer countries tend to be more appreciative of their regime than people in poorer countries (Acemoglu and Robinson 2012). Furthermore, we also know that citizens in political systems with better functioning bureaucracies (=high levels of quality of government, QoG) tend to be more content with how their democracy works (Holmberg and Rothstein 2012). A good economy as well as an impartial bureaucracy matters and thus need to be statistically controlled before we can say anything more definitive about a possible and separate impact of institutional trust on people's evaluation of how their democratic regime functions. GDP/capita and QoG constitute our baseline model on top of which the institutional trust variables have to prove their potential independent effects on democratic regime support.

The model is an aggregate level model intended to be applicable primarily on the national level. State functionalism and how it is related to different forms of institutional trust is our research area.

\footnotetext{
${ }^{2}$ Another useful measurer of comparative institutional trust is the European Social Survey (ESS). We will as well use ESS data. However, ESS only covers European countries and includes a limited number of institutions (eight).
} 
But some of the model's implications could as well be tested on the individual level given the availability of relevant data. As it happens, reasonably suitable micro level data is to be found in our native Sweden. Hence, we will test the model on the aggregate as well as on the individual level. ${ }^{3}$

\section{Data Sources}

The by far best data source for our institutional trust variables is the World Value Survey. Beginning in the 1980s and continuing up to date in six consecutive waves, trust in some sixteen different institutions has been systematically measured in about seventy countries (Inglehart 1997). The institutions covered include electoral and judicial ones as well as bureaucratic, civil society, economic, religious and media institutions. We will work with the measurements taken in the early 2000s. Trust indices will be constructed based on results for more than one institution, and these indices will be used in the model tests.

The most theoretically important indices will be the ones involving trust in input oriented democratic institutions like Parliament and Political Parties and legal institutions like the Justice System and the Police. ${ }^{4}$ Regrettably, no index concerning trust in public administration can be constructed since WVS only contains one relevant item - trust in Civil Services. And, to make things worse, that item is highly questionable. What does it measure? Civil Service, we are afraid, can mean very different things in different national contexts and is as well sensitive to translation nuances. ${ }^{5}$

Our dependent variable, people's satisfaction with the working of democracy in their country, is not included in the WVS. Instead WVS has chosen to measure a related but quite different concept,

\footnotetext{
${ }^{3}$ An important criticism made by Kittel (2006) is the lack of robustness that often seem to appear in macro-quantitative comparative research in the social sciences. We agree with this criticism but we do not think the solution is to stop conducting cross-sectional country comparative research. Instead we argue that theoretical propositions of individual behavior should be empirically tested on different levels of aggregation. Hence, our approach is to run our models on the aggregated level across countries and then, in a second step, we are zooming in and testing the same models among individuals in one of the countries included in our sample. By this approach we are extending the validity and generalizability of our findings.

${ }^{4}$ WVS measures trust in two other political institutions, Government and the United Nations. Neither of them is included in our democratic/political trust index since Government is more of an output institution and the UN is not a national institution.

${ }^{5}$ The translation of Civil Services in the Swedish questionnaire is "Civilförvaltningen", a terminology not used at all in Sweden for public administration. The best translation would instead probably be "Offentlig förvaltning". We have not systematically looked at how "Civil Services" has been translated into other languages. However, a newly started project at University of Gothenburg is about to do just that, among other things. See Dahlberg and Holmberg (2015) Language Effects in Surveys (LES).
} 
namely how citizens evaluate the development of democracy in their country. And since a development assessment is something else than an assessment of how well something works - an evaluation of direction versus an evaluation of level - we cannot use WVS data for our dependent variable. But since our main empirical test is to be done on the aggregate national level, we are not necessarily stuck with WVS data. We can look elsewhere to find information on how citizens evaluate the working of their democracy, and then aggregate that information to the national level. A search like that led us to CSES - the Comparative Study of Electoral Systems. CSES is a cooperative project involving national election studies in most electoral democracies (Klingemann 2009). Since the mid 1990s CSES has carried out four waves of comparative election studies in some forty democracies. And the SWoD measure has been included as a regular feature in all the surveys. Thus, our dependent SWoD variable is taken from early 2000 CSES data ${ }^{6}$

The control variables, economic situation and the quality of government, are both taken from the Quality of Government data bank (Dahlberg et al. 2011). Economic situation is rather conventionally defined as GNP/capita. Quality of Government (QoG) on the other hand is a more novel concept and thus less self-evidently measured. We have chosen to apply two related but differently operationalized versions of QoG. One is the Government Effectiveness Index developed by the World Bank (Kaufmann 2004, Kaufmann et al. 2010, Magalhaes 2013). The other is an Impartial Public Service (IPS) index designed within the Quality of Government Institute (Rothstein and Teorell 2012, Dahlström, Lapuente and Teorell 2012). The two measures are correlated with each other on a high level $(r=.87)$, but they are not identical. By applying both of them separately as well as in tandem, we are giving QoG an extra strong controlling position in the model test. However, the outcome of these robustness tests does not change any conclusions in this paper. Consequently, in the analyses to follow we will only apply the IPS Index from the QoG institute.

Our micro level test will be performed based on data from the SOM Institute at the University of Gothenburg. The Institute carries out annual nationwide and regional surveys in Sweden since 1986 (Weibull, Oscarsson and Bergström 2013). We will use data from the 2010 and 2012 national surveys (Holmberg, Weibull and Oscarsson 2011). They included the SWoD measure, institutional trust results for twenty one different institutions and data relevant for our two control variables -

${ }^{6}$ The guiding principle for matching CSES data with WVS data has been to use trust items from the wave that most closely matches the year for the CSES modules. When data has been missing for the corresponding wave, the intermediate WVS wave has been used and thereafter the subsequent WVS wave in relation to the CSES. 
economic situation and quality of government. ${ }^{7}$ Data on household income will be used to tap peoples' economic circumstances.

The QoG variable is more difficult to nail down in a reasonable and comparative way. However, in the SOM data bank there are extensive measurements of how citizens evaluate the job performance of a whole set of public services like health care, tax collection, primary schools, and the Public Employment Service. Consequently, we can get measures of how ordinary citizens assess the quality of government. Admittedly, it is not the same as the World Bank's or the QoG Institute's quality of government measures. WB and QoG primarily rely on expert judgments, not evaluations done by citizens. The SOM measure will in contrast be based on assessments by ordinary people. But maybe this difference is not so very important. Comparative studies on perception of corruption among experts and elites as well as among common citizens indicate very small differences (Holmberg 2009). Upstairs or downstairs, expert or laymen, at least corruption tends to look the same across countries. Perhaps that is also true for the broader phenomenon quality of government?

\section{It's Judicial and Electoral Institutions, Stupid}

Bill Clinton's campaign manager James Carville (2009) once answered the question what decided elections with: It's the economy, stupid! Bo Rothstein and others who have pointed to the importance of well-functioning political and especially judicial institutions in building societal trust and more specifically in building inter-personal trust, could have exclaimed: It's judicial and electoral institutions, stupid, when asked what kind of institutions are most important in creating and sustaining support for the performance of democracy. And they would have been right, at least preliminary and only looking at bivariate relationships.

Among thirty four countries, correlations between trust in sixteen different institutions and the aggregated level of citizens' satisfaction with how their democracy functions are clearly strongest for some judicial and electoral institutions like the Police, the Judicial System, Political Parties and

\footnotetext{
${ }^{7}$ The SOM Institute's measures of institutional trust include trust in Parliament and Political Parties as well as trust in Courts and Police; thus indices for our democratic/political input variables as well as for our legal variables can be constructed. However, SOM's institutional trust measurement does not include any measurement of trust in Public Administration (or Civil Services). Consequently, we cannot on the individual level test the impact of trust in Public Administration on Satisfaction with the Working of Democracy.
} 
Parliament (see Table 1). ${ }^{8}$ Trust in Economic, Civil Society, Media and Religious institutions show up with weaker or even in some cases with negative relationships with SWoD. As is shown in Table 1, the four institutions with the strongest trust associations with how citizens evaluate the working of their democracy, are first the Political Parties, second Parliament, third the Justice System and fourth the Police. Civil Services, whatever that connotes in different national contexts, are ranked number eight. Government - a political institution but more output oriented and more partisan shows up further down the list on rank ten.

Trust in the four top electoral and legal institutions are correlated about the .50 level with the aggregated SWoD measure among our thirty four countries. In other words, there is a pretty substantial bivariate relationship between trust in central input focused electoral institutions and SWoD as well as between trust in judicial institutions and peoples' support for the way their democracy works. Comparable associations for trust in other types of institutions tend to be lower. For example, the correlation between SWoD and trust in Civil Service and Government are .39 and .37, respectively, while the comparable correlations with trust in Parliament and the Justice System are .52 and .51. Apparently, what matters most is trust in democratic input institutions and judicial institutions.

\footnotetext{
${ }^{8}$ The countries included are: 1. Albania, 2. Australia, 3. Brazil, 4. Bulgaria, 5. Canada, 6. Chile, 7. Czech Republic, 8. Finland, 9. France, 10. Germany, 11. Hungary, 12. Italy, 13. Japan, 14. Kyrgyzstan, 15. Lithuania, 16. Mexico, 17. Netherlands, 18. New Zealand, 19. Norway, 20. Peru, 21. Poland, 22. Republic of Korea, 23. Romania, 24. Slovenia, 25. South Africa, 26. Spain, 27. Sweden, 28. Switzerland, 29. Taiwan, 30. Thailand 31. Turkey, 32. United Kingdom, 33. Uruguay, 34. USA. We have excluded countries that were classified as "not free" according to the Freedom House index at the time when data was collected (see Freedom in the World. Selected data from Freedom House's annual global survey of political rights and civil liberties". www.freedomhouse.org).
} 
TABLE 1, CORRELATIONS BETWEEN SATISFACTION WITH THE WORKING OF DEMOCRACY (SWOD) AND TRUST IN SOCIETAL INSTITUTIONS IN THIRTY FOUR COUNTRIES (PEARSON'S R).

\begin{tabular}{lll}
\hline & Institution & Correlations $(\mathbf{r})$ \\
\hline 1. & Political Parties & .56 \\
2. & Parliament & .52 \\
3. & Justice System & .51 \\
4. & Police & .51 \\
5. & Labour Unions & .50 \\
6. & Environmental Movement & .44 \\
7. & Women's Movement & .42 \\
8. & Civil Services & .39 \\
9. & Humanitarian Organizations & .39 \\
10. & Government & .37 \\
11. & Major Companies & .14 \\
12. & Armed Forces & .10 \\
13. & United Nations & -.14 \\
14. & Press & -.17 \\
15. & Churches & -.20 \\
16. & Television & -.22 \\
\hline
\end{tabular}

Comment: The data on SWoD comes from National Election Studies in the years 1996-2006 administrated through CSES. The trust data are from wave three, four and five of WVS.

To illustrate the relationships more vividly six scatter plots are depicted in Figure 1. All with SWoD as the dependent vertical axis and with trust in Police, Parliament, Justice System, Political Parties and Armed Forces as well as Press as independent horizontal axes. Armed Forces and Press are included to demonstrate how the results look for two institutions with no relationship between the degrees of trust and how citizens evaluate how their democracy works. 
FIGURE 1, IMPACT OF INSTITUTIONAL TRUST ON CITIZENS' REGIME SUPPORT (SWOD): SIX ILLUSTRATIVE SCATTERPLOTS.
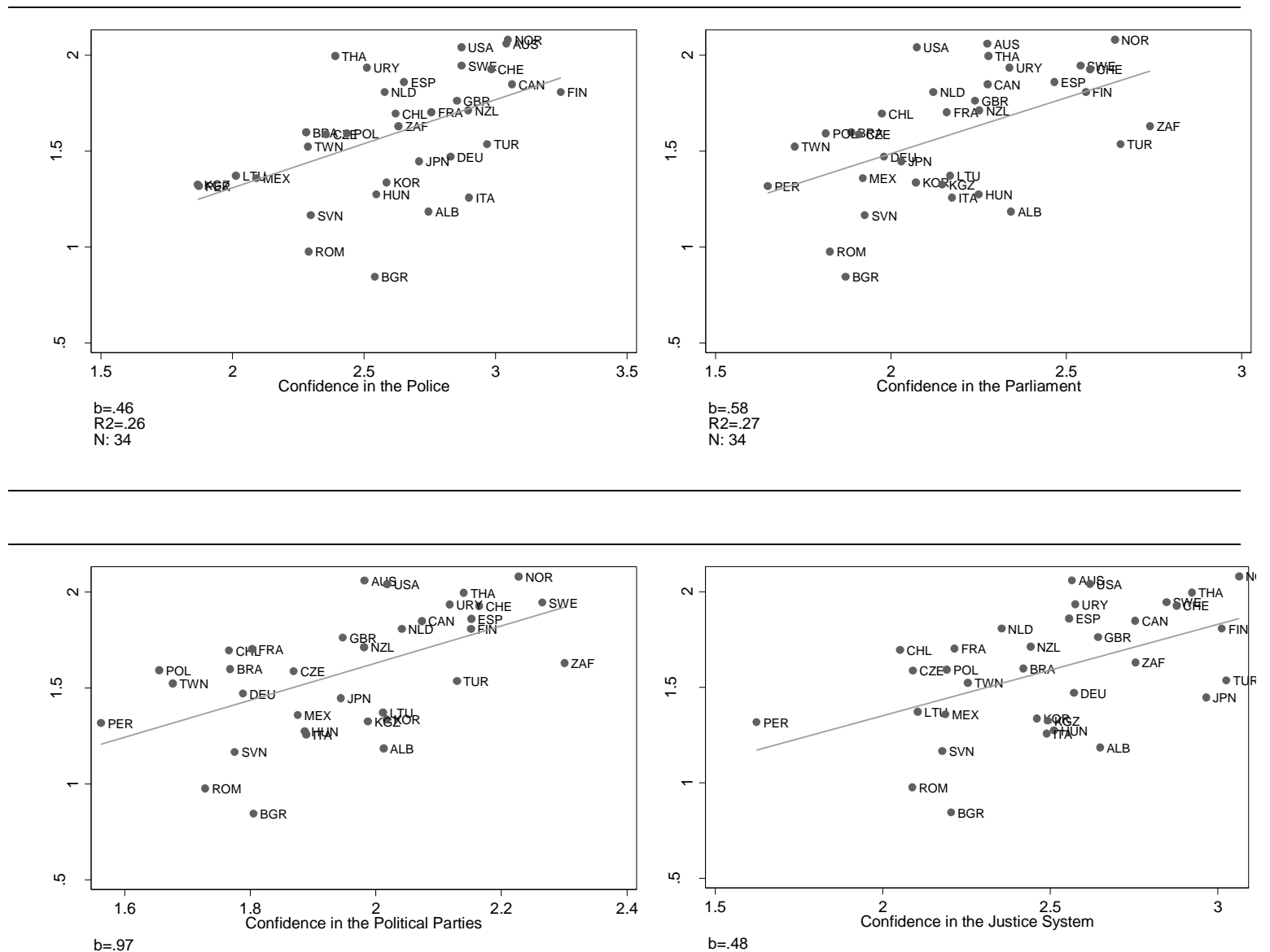
$\mathrm{b}=.97$
$\mathrm{R} 2=.31$
$\mathrm{~N}: 34$

$b=.48$
$R 2=.26$
$N: 34$
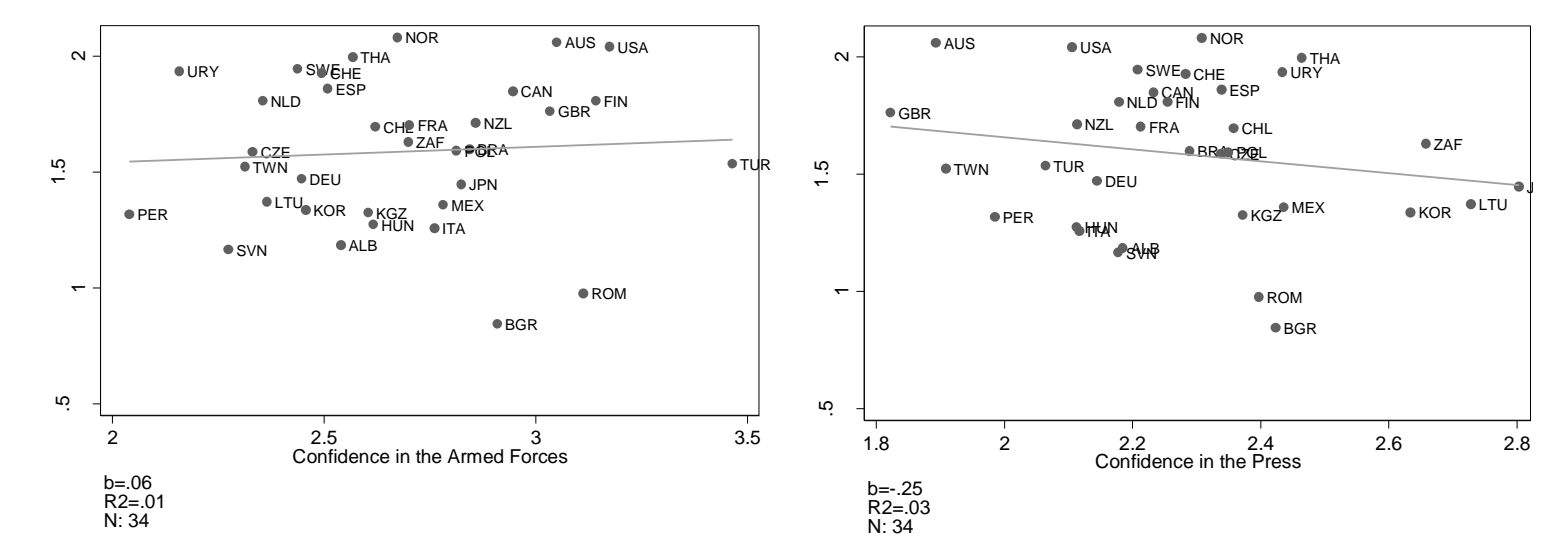
Comment: The scatterplots are based on data from CSES (for the SWoD-variable, scaled 1-4) and from WVS (for the trust variables, scaled 1-4). The higher SWoD and the higher trust scores, the more citizens tend to be satisfied with the working of their democracies and have more confidence in the relevant institutions.

The strong positive correlation between SWoD and trust in the Judicial System and in the Political Parties is very evident in the scatter plots with countries like Norway, Switzerland and Sweden where people tend to trust parties as well as the rule of law at the same time as they tend to be satisfied with the working of their democracies - in the upper right corner and other countries like Bulgaria, Slovenia and Romania, with citizens less trusting and less satisfied in the lower left corner. The case of trust in the Armed Forces - in our sample of thirty four democracies - reveals an almost total lack of association between how people assess how their democracy functions and the extent to which the Armed Forces are trusted. The scatter plot involving trust in the Press also reveals an almost non-existent correlation with SWoD, although in this case the very weak association is actually negative. The empirical reason for the slight negative relationship is that citizens in countries like Australia, United Kingdom and USA tend to be satisfied with how there democracies work at the same time as they tend not to trust the Press, while in other countries like in Bulgaria and Romania people are less satisfied with the working of their democracy despite the fact that they tend to trust the Press. Obviously, trust in media - Press as well as Television - is of less importance in sustaining positive citizen evaluations of the functioning of democratic regimes than is sometimes portrayed in the literature (Färdigh 2013, Norris 2008b, Sussman 2001).

\section{Effects of Institutional Trust Still Remains After Controls}

No matter if we model institutional trust as a causal factor behind citizens's satisfaction with the working of their democracy or only talk of attitudinal co-variations, we want to make sure whether our empirical bivariate relationships withstand some obvious statistical controls. The relevant and minimal controls in our case are to account for the effects of quality of government and economic situation - our baseline model. The purpose of the regression analysis in Table 2 is to do just that. In our sample of thirty four democracies, $\mathrm{SWoD}$ is regressed on two trust indices combining trust in two democratic/political input institutions and two judicial institutions, on an index measuring 
impartiality in public administration, and on GDP per capita. Bivariate as well as multivariate regression coefficients are presented in the table. ${ }^{9}$

TABLE 2, REGRESSING SATISFACTION WITH THE WORKING OF DEMOCRACY (SWOD) IN THIRTY FOUR COUNTRIES ON TRUST IN ELECTORAL AND JUDICIAL INSTITUTIONS, ON IMPARTIAL PUBLIC ADMINISTRATION AND ON GDP/CAPITA (OLS REGR. COEFF; STD. ERR. WITHIN PARENTHESES).

\begin{tabular}{|c|c|c|c|c|c|}
\hline & $\begin{array}{l}\text { Bivariate } \\
\text { SWoD }\end{array}$ & $\begin{array}{l}\text { Model } 1 \\
\text { SWoD }\end{array}$ & $\begin{array}{l}\text { Model } 2 \\
\text { SWoD }\end{array}$ & $\begin{array}{l}\text { Model } 3 \\
\text { SWoD }\end{array}$ & $\begin{array}{l}\text { Model } 4 \\
\text { SWoD }\end{array}$ \\
\hline Electoral Trust Index & $1.71^{* \star *}(.40)$ & - & $1.17^{* * *}(.36)$ & - & $1.72^{\star \star \star}(.57)$ \\
\hline Judicial Trust Index & $1.89^{* * *}(.41)$ & - & - & $.85(.54)$ & $-.96(.79)$ \\
\hline Impartial Public Admin. & $.74^{\star \star *}(.12)$ & $.87^{\star * \star}(.24)$ & $.70^{\star * \star}(.20)$ & $.73^{\star \star *}(.23)$ & $.77^{\star * *}(.23)$ \\
\hline GDP/cap(In) & $.46^{* *}(.18)$ & $-.16(.27)$ & $-.11(.21)$ & $-.21(.24)$ & $-.03(.24)$ \\
\hline Constant & - & $4.06(2.60)$ & 2.99 (1.99) & $4.08^{\star}(2.21)$ & $2.46(2.29)$ \\
\hline R-squared & - & .42 & .54 & .44 & .54 \\
\hline $\mathbf{N}$ & 34 & 34 & 34 & 34 & 34 \\
\hline VIF (Mean): & - & 2.14 & 1.87 & 2.13 & 3.01 \\
\hline
\end{tabular}

Comment: $p>|t|=.01^{* * *} ;=.05^{* *} ;=.10^{*}$. Standard errors are boot-strapped with 1000 replications. SWoD, the dependent variable, is taken from CSES and scaled 1 (low satisfaction) to 4 (bigh satisfaction). The independent variables are all scaled between 0 (low trust, low impartiality and low GDP per capita) and 1 (bigh trust, high impartiality and high GDP per capita). The Trust Indices, based on WVS data, combines trust in two electoral institutions and two judicial institutions -

Political Parties and Parliament as well as Police and Justice system (see Table 1). The Impartial Public Administration Index builds on a global expert survey run by the Quality of Government Institute (see Holmberg and Rothstein 2012). GDP/capita is taken from the World Bank - World Development Indicators (World Bank WDI 2013), provided by Teorell et. al. (2013). We have here elaborated with different measures of economy, such as for example GDP-growth/cap, but our results remain unaffected.

\footnotetext{
${ }^{9}$ We have also tested to include trust in Civil Services as an independent variable, although we suspect the validity of that measure to be doubtful. The bivariate regression outcome in our sample of 34 countries is that the relationship between trust in Civil Services and SWoD is significant and has an expected sign - the more trust in Civil Services the more Satisfaction with the Working of Democracy. However, the effect is less pronounced than the comparative effects of the democratic/political input institutions and the judicial institutions. After controls, the effect of Civil Services not only becomes insignificant. It ends up with a wrong sign. Our conclusion is not that trust in Public Administration does not play a role when it comes to how satisfied citizens are with how well their democracy works. Instead, our conclusion is that the jury is still undecided. The WVS measurement of trust in Public Administration (Civil Services) is not good enough to render a more conclusive verdict.
} 
A first observation is that the two trust indices as well as the impartiality index all show strong bivariate relationships with how people evaluate the working of their democracy. The economic variable, GDP per capita, also has an expected impact on SWoD, but to a weaker extent. The first rounds of multivariate tests demonstrate the same basic result. Institutional trust separately via democratic input institutions as well as separately via judicial institutions, and impartial public service all have independent and strongly significant effects on citizens' assessment of how their democracy works, while the effect of economic circumstances is clearly weaker and non-significant. ${ }^{10}$ However, when we test the impact of the two trust indices together in multiple regressions, Judicial trust fail to reach an independent significant effect level although the effect signs in both of the separate cases (model 2 and 3) are the correct and expected ones; the higher trust in democratic input institutions and in judicial institutions the better SWoD. But the limited number of cases and the high correlation between our two trust indices $(\mathrm{r}=.75)$ mean that we run into a serious multicollinearity problem preventing us from being able to really test the separate effect of the Judicial trust factor. ${ }^{11}$ Trust in legal institutions has an impact on how people judge how well their democracies function. How strong that impact is taken separately and under control for trust in other relevant institutions we do not know and cannot tell given the limited number of countries at our disposal. ${ }^{12}$

\footnotetext{
${ }^{10}$ As mentioned earlier, our analyses on the aggregated level are based on data from two different data sources. Our dependent variable (SWoD) is taken from Comparative Studies of Electoral Systems (CSES) module 1,2 and 3; while the independent variables on Electoral and Judicial Trust is taken from time corresponding waves in the World Value Survey (WVS). An SWoD item is, however, included in the European Social Survey (ESS) as well reading: On the whole, how satisfied are you with the way democracy works in [country]? In contrast to the CSES questionnaire (where the response options are 1 - not at all satisfied to 4 - very satisfied), the ESS response options are based on an 11 point scale, stretching from 0 (extremely dissatisfied to 10 (extremely satisfied) (for more information, see: www.europeansocialsurvey.org/data). The CSES and the ESS survey items are highly correlated in our sample of 34 countries $(r=.81)$, which make them not identical but at least very close. When also incorporating countries from the ESS in our dataset, the number of cases increases to 42. The outcome from such a maneuver is that all of our relationships become even stronger. For example, the bivariate relationship between confidence in Political Parties and SWoD is $\left(b=1.87\right.$ and $\left.R^{2}=.54\right)$ with ESS data included compared to $\left(b=.97\right.$ and $\left.R^{2}=.31\right)$ without ESS data. The bivariate relationship between confidence in the Justice System and SWoD is $\left(b=1.06\right.$ and $\left.R^{2}=.51\right)$ with ESS data included compared to $\left(b=.48\right.$ and $\left.R^{2}=.26\right)$ without ESS data. However, the fact that all our results are strengthened when ESS data is included is not very surprising since ESS only are adding European countries, where both trust in different institutions as well as SWoD in general are higher compared to countries outside Europe. Including EES data in our study would in relative terms "over-represent" Europe (let be that the sample is not representative as such in terms of countries included). Not including ESS (or Eurobarometer) data gives our hypothesis more of an uphill battle.

${ }^{11}$ The sudden loss of significance and change of direction in the effect is often an indication of multicollinerarity, which here also is indicated by the low tolerance value for the Judicial Trust Index in model $4(1 / \mathrm{VIF}=.23)$.

${ }^{12}$ The very strong relationship between our two trust indices makes it possible to combine them and theoretically talk of trust in four central "procedural" electoral-judicial institutions - in Parliament and Political Parties (free and fair elections) as well as in Judicial System and Police (rule of law). For this reason we have also elaborated with an interaction term between the two indices but due to multicollinearity, the model did not perform well.
} 
Notwithstanding the limitation of not being able to really separate the impact of trust in democratic input institutions from the impact of trust in legal institution. Our conclusion is that countries where citizens tend to appreciate how democracy functions also are countries where people tend to trust societal institutions, especially democratic input and judicial institutions, and where we find more impartial public administrations. Whether the country is more or somewhat less successful economically is of a lesser importance.

\section{A Micro Level Test - The Case of Sweden}

Obviously, in all kinds of scientific endeavors, it is important to test theories not only in one but in many different ways. Multiple tests are reassuring if they come to the same result. And cause for more tests and perhaps rethinking if they come to divergent outcomes. Consequently, it is an important advantage that we through our access to data from the SOM Institute's annual Swedish surveys can test our model using micro level individual data.

On the individual level and at least among Swedes, the SWoD variable tends to be positively correlated with trust in all kinds of societal institutions; but to very different degrees. The results in Table 3, based on the 2012 SOM survey, show the strongest correlations for some political institutions Government, Parliament and Political Parties - and weakest relationships for institutions like Trade Unions, the Royal House, Primary Schools, the Swedish Church, Banks and the Daily Press. Two judicial institutions - Courts and Police - are ranked in the upper half among the twenty one institutions, but have only medium sized correlations. 
TABLE 3, CORRELATIONS BETWEEN SATISFACTION WITH THE WORKING OF DEMOCRACY (SWOD) AND TRUST IN SOCIETAL INSTITUTIONS AMONG SWEDISH CITIZENS (PEARSON'S R).

\begin{tabular}{lll}
\hline & Institution & Correlations $(\mathbf{r})$ \\
\hline 1. & Government & .52 \\
2. & Parliament & .50 \\
3. & Political Parties & .43 \\
4. & The Riksbank & .38 \\
5. & EU Commission & .35 \\
6. & Local Governments & .35 \\
7. & Courts & .34 \\
8. & EU Parliament & .33 \\
9. & Universities & .29 \\
10. & Police & .28 \\
11. & Major Companies & .28 \\
12. & Health Care & .27 \\
13. & Radio/Television & .25 \\
14. & Armed Forces & .24 \\
15. & United Nations & .23 \\
16. & Press & .23 \\
17. & Banks & .22 \\
18. & Swedish Church & .21 \\
19. & Primary School & .20 \\
20. & Royal House & .20 \\
21. & Trade Unions & .15 \\
\hline
\end{tabular}

Comment: The data come from an annual Swedish survey conducted in 2012 by the SOM Institute at the University of Gothenburg. The number of respondents is between 4500 and 6000.

Disregarding institutions not included in both the aggregated macro analysis and in the micro individual level Swedish analysis, the similarity of the outcomes is remarkable. The rank order correlation between the results in Table 1 and 3 is .67 (Spearman's Rho). And most significantly, macro as well as micro, electoral and judicial institutions tend to have the strongest relationships with how people judge the working of democracy - or in the case of judicial institutions among Swedes, at least be placed in the upper half of the institutional ranking.

The rather striking resemblance between our macro and micro results is still there when we move from bivariate relationships and rank orders to multivariate controls. In Table 4, Swedes' satisfaction with the way democracy works is regressed on two separate trust indices footed on confidence in democratic input institutions (Political Parties and Parliament) as well as in legal institutions 
(Courts and Police), on a public service performance index based on how citizens' evaluate the job performance of ten Swedish public authorities/public service areas, and on household income.

TABLE 4, REGRESSING SATISFACTION WITH THE WORKING OF DEMOCRACY (SWOD) AMONG SWEDES ON TRUST IN ELECTORAL AND JUDICIAL INSTITUTIONS, ON ASSESSMENTS OF PUBLIC SERVICE PERFORMANCE, AND ON HOUSEHOLD INCOME (OLS REGR. COEFF; STD. ERR. WITHIN PARENTHESES).

\begin{tabular}{|c|c|c|c|c|c|}
\hline & Bivariate & Model 1 & Model 2 & Model 3 & Model 4 \\
\hline Electoral Trust Index & $2.12^{\star \star \star}(.06)$ & - & $1.48^{\star \star \star}(.06)$ & - & $1.35^{\star \star \star}(.07)$ \\
\hline Judicial Trust Index & $1.40^{* * *}(.06)$ & - & - & $.95^{\star \star \star}(.07)$ & $.39^{\star \star \star}(.07)$ \\
\hline Public Service Performance Index & $1.46^{\star * *}(.08)$ & $1.50^{* \star *}(.08)$ & $.82^{\star * *}(.08)$ & $.94^{\star \star *}(.09)$ & $.64^{* \star *}(.08)$ \\
\hline Household Income & $.32^{\star \star *}(.04)$ & $.34^{\star \star *}(.04)$ & $.18^{* * *}(.03)$ & $.27^{\star \star \star}(.04)$ & $.17^{\star \star \star}(.03)$ \\
\hline Constant & - & $1.89^{* \star *}(.05)$ & $1.59^{* * *}(.05)$ & $1.66^{* * *}(05)$ & $1.52^{* * *}(.05)$ \\
\hline Adj. R-squared & - & .13 & .29 & .19 & .30 \\
\hline N: & 2831 & 2831 & 2831 & 2831 & 2831 \\
\hline
\end{tabular}

Comment: $p>|t|=.001^{* * *} ;=.01^{* *} ;=.05^{*}$. Individual level Swedish data from a SOM Institute survey in the fall of 2010. The dependent variable (SWoD) is coded 1 (low satisfaction) to 4 (bigh satisfaction). All independent variables are scaled from 0 (low trust, low performance assessments, low income) to 1 (bigh trust, bigh performance assessments, high income). The trust indices combines trust in four electoral-judicial institutions - Political Parties and Parliament as well as Police and the Courts. The Public Service Performance index is based on bow Swedes evaluate the job performance in ten public service areas (see Johansson and Holmberg 2011). Survey respondents provide the information behind the household income variable. Thanks to Per Hedberg for help with data runs on the SOM material.

Given the number of respondents - about 3000 - it is not surprising that all coefficients are highly significant. Thus, in this case it is the size of the coefficients that are of most interest. And here we find an outcome we recognize from the previous macro analysis, although it is more evident on the micro level. Peoples' trust in democratic input institutions as well as in legal institutions - and assessment of the performance of the public sector (=quality of government) - are strongly related to how the working of Swedish democracy is evaluated; political trust stronger than performance assessments. Trust in judicial institutions has the expected positive impact as well but not on the same level. The correlation between our two trust indices is medium high $(+.51)$. The independent effect of trust in legal institutions get to be somewhat overshadowed by trust in the related trust in political institutions. The economic status of citizens is also connected to how the working of democracy is perceived, but clearly on a much lower level. 
The conclusion is the same as before when we analyzed aggregated national results. Overall satisfaction with how Swedish democracy works tend to be most pronounced among people who trust central electoral and judicial institutions and who perceive that the job performance of Swedish public authorities is good. And here the direct effect of institutional trust is stronger than the direct effect of the job performance assessments of how public bureaucracies work. Whether people are rich or poor matter less.

\section{Causal Direction}

Our model is based on the simplified notion that institutional trust "causes" regime support, not the other way around. And that is of course a oversimplification. In reality we must assume that trust impacts support at the same time as support impacts trust. We have a circular process with feedback loops.

One way to highlight that peoples' SWoD are influenced by institutional trust at an earlier time $\left(\mathrm{t}_{-1}\right)$ and that citizens' trust levels as well are impacted by how they previously evaluated the working of their democracy $\left(\mathrm{t}_{-}\right)$is to apply a dynamic model on panel data. We have preliminary done that using Swedish data from a Citizen Panel put together at the Department of Political Science in Gothenburg (Oscarsson, Dahlberg and Martinsson 2013). The outcome is very instructive. The effects both ways turn out to be substantial and statistically significant. Institutional trust at $\mathrm{t}_{-1}$ has an effect on SWoD at time-point $t$, and SWoD at $t_{1}$ has an effect on institutional trust at time-point t. There is an effect circle. But in that feedback loop it looks as if the more specific attitude, i.e. institutional trust, has a somewhat larger impact on the more general attitude SWoD. ${ }^{13}$ At least that

\footnotetext{
${ }^{13}$ In situations with reversed causality in cross-section data, the effects in terms of absolute levels could be overstated since the relationships may suffer from endogeneity. In order to sort out such a problem panel data is needed. In the Swedish Citizen Panel (Oscarsson, Dahlberg and Martinsson 2013) hosted by the Laboratory of Opinion Research (LORe) at the University of Gothenburg, approximately 15000 Swedish citizens are surveyed on a regular basis, usually every sixth month starting back in late 2010 (for more information, see. www.lore.gu.se/surveys/citizen). The Citizen Panel consists of, amongst others, a standing block of survey questions where SWoD and trust in Parliament are included. In total, the survey contains seven waves which imply that we have the opportunity to run auto-regressive models on SWoD and institutional trust. In this respect we specify a simple LDV model such as: $\Delta Y_{i}=\alpha+(\gamma-1) Y_{i, t-1}+\beta X_{i,-1}+$ $e_{t}$. Starting with the effect of trust in Parliament at $t_{-1}$ on $S W o D$ at $t$, under control for the effect of $S W_{0 D}$ at $t_{-1}$, the main effect is $\left(b=.27^{* * *} R^{2}=.21\right)$ while the effect of $S W o D$ at $t_{-1}$ on trust in Parliament at time-point $t$, under control for the effect of trust in Parliament at $t_{-1}$, is $b=.22^{\star \star \star} R^{2}=.18$. The results become, on the marginal, even more pronounced when longer lags are used. These outcomes suggest that the relationship is dynamic and that causes are going in both direc-
} 
is the result in our analysis using SWoD and trust in parliament as the operational measures. However, it is important to emphasis that the effects go both ways. Consequently, our model specifying an impact of institutional trust on regime support is relevant. Granted though, that the estimated effects of institutional trust are going to be on the high end since we have not controlled away the reversed effects of SWoD on institutional trust.

\section{Institutional Trust Matters}

Our main results can be simply stated. There is truth in the saying that trust builds and sustains societies. In our study, based on macro as well as micro level data, we have shown that institutional trust has an independent effect on regime support. And the kind of institutional trust that is most important is trust in political/democratic input institutions and in judicial institutions. Trust in other societal institutions like economic institutions, media institutions, religious institutions, civil society institutions, and public service institutions matter less. ${ }^{14}$

The conclusions, however, are not stand alone facts, independent of our theoretical model. On the contrary, the results are to a degree contingent on the model and the controls applied. In our case we have squared a complex reality by specifying a model with only three/four explanatory factors. And we have not specified nor tested any indirect effects between our explanatory variables. Furthermore, the model presupposes a uni-directional causal mechanism that we for sure know is a simplification. Peoples' evaluations of how their democracy works influence the degree to which they trust vital societal institutions at the same time as trust in central institutions impacts how citizens assess the working of their democracy. We can talk of feedback loops and vicious or virtues circles (Norris 2000). However, our tests have mainly been stationary at one point in time, not dynamic over time as they ideally should have been.

We like to conclude with two easy to grasp and very visual graphical models - one on the individual micro level and one on the macro level. Both models include our three explanatory factors as well

tions. There is, however, a slightly stronger impact from trust in Parliament on SWoD than the other way around, which is supporting the theoretical approach of the current paper.

${ }^{14}$ With the reservation that our test of the effect of trust in public administration is questionable since it is only based on macro data aggregated from WVS-measurements of trust in Civil Services. And those measurements we believe may not accurately measure trust in public administration. Our micro level tests using data from the Swedish SOM Institute did not include any measure of trust in public administration. 
as the dependent variable regime support measured as satisfaction with the way democracy works. In the models, we have estimated not only direct effects on SWoD but also a potential indirect effect of quality of government through institutional trust on SWoD (see Figure 2). The measure of institutional trust is operationalized as our index covering democratic electoral input institutions.

FIGURE 2, ESTIMATING THE EFFECTS OF TRUST IN ELECTORAL INSTITUTIONS, OF QUALITY OF GOVERNMENT AND OF ECONOMIC WEALTH ON CITIZENS' SATISFACTION WITH THE WORKING OF DEMOCRACY IN THEIR COUNTRIES: STRUCTURAL EQUATION MODELS.

Structural Equation Model: National Level Data/ 34 Countries.

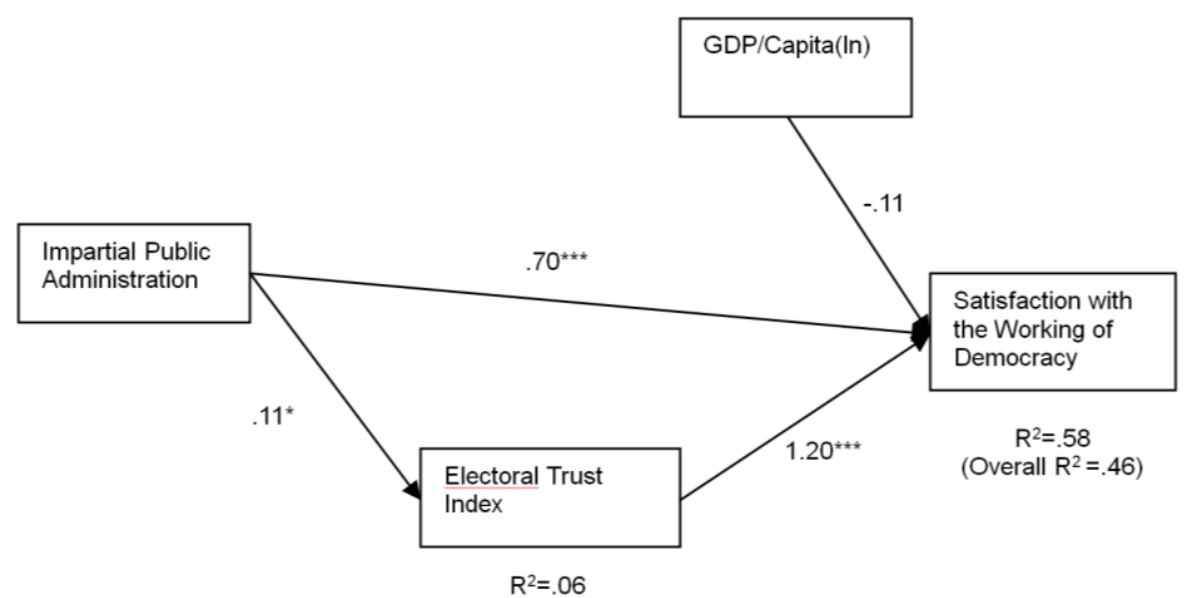

Structural Equation Model: Individual Level Data/ Swedish Citizens.

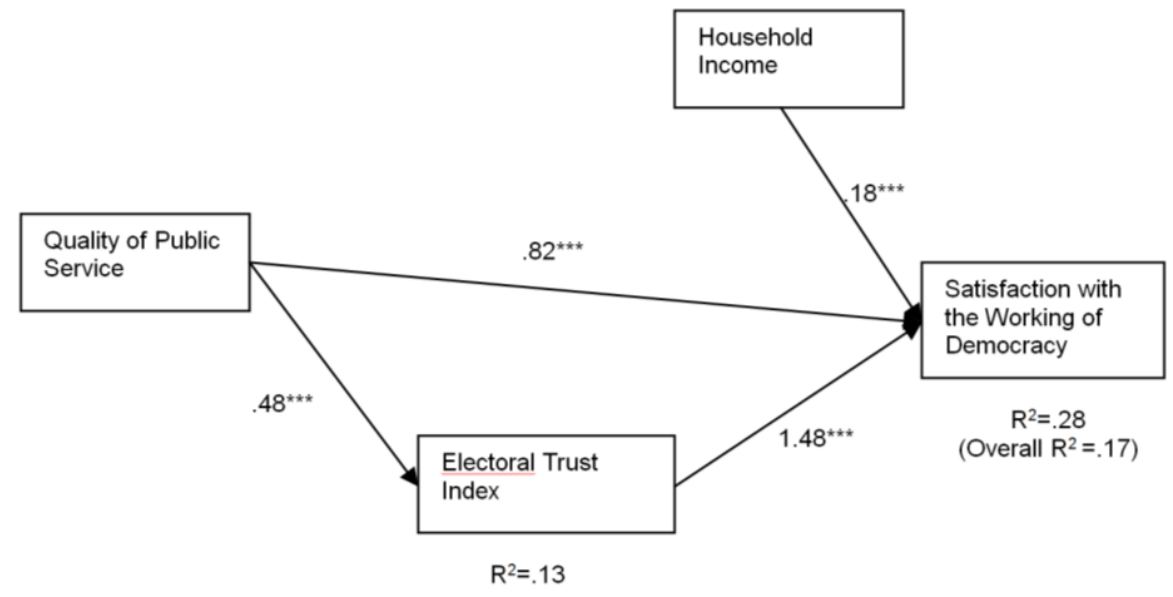


Comment: For details about variables and codings, see table 2 and 4, respectively. N:34 (National level); N:2 831 (Individual level). Maximum Likelihood Estimation. $p>|t|=.001^{* * *}$; $=.01 * * ;=.05^{*}$.

The results of the macro and micro tests are as before the same. Trust in democratic electoral input institutions as well as quality of government, measured as quality and impartiality of public administration, have independent direct effects on how citizens evaluate how their democracy functions; electoral trust somewhat more than quality of government. However, quality of government also has an indirect effect on regime support. That indirect effect goes via institutional trust. Quality of government influences institutional trust which in turn impacts regime support.

When it comes to regime support (and regime legitimacy) institutional trust matters; especially trust in electoral and judicial institutions. And quality of government matters. Economic factors, however, matter less in this instance. Political factors rule, not economical. The economists Daron Acemoglu and James Robinson repeatedly stress the importance of political institutions in their book Why Nations Fail (2012). Our results render further support to their conclusions. But we are more specific. Nations succeed when there is trust in electoral and judicial institutions and when there are impartial public administrations. 


\section{REFERENCES}

Acemoglu, D. and Robinson, J. 2012. Why Nations Fail. New York: Crown Business

Alesina, A. and La Ferrara, E. 2000. The Determinants of Trust. Cambridge; MA: NBER

Carville, J. 2009. 40 More years. New York: Simon \& Schuster.

Charron, N. and Lapuente, V. 2012. In Democracy We Trust, But How Much? In Holmberg, S. and Rothstein, B. (Eds.) Good Government. The Relevance of Political Science. Cheltenham: Edward Elgar.

Dahlberg, S. Dahlström, C., Norell, V. and Teorell, J. 2011. The Quality of Government Institute Quality of Government Survey: A Report. Gothenburg: The QoG Institute.

Dahlström, C., Lapuente, V. and Teorell, J. 2012. Public Administration Around the World. In Holmberg, S. and Rothstein, B. (Eds.) Good Government. The Relevance of Political Science. Cheltenham: Edward Elgar.

Esaiasson, Peter and Ottervik, Mattias 2014. Does Compliance Correlate With Political Support? Göteborg: QoG Institute.

Fuchs, D., Guidorossi, G. and Svensson, P. 1995. Support for the Democratic System. In Klingemann, H-D. and Fuchs, D. (Eds.) Citizens and the State. Oxford: Oxford University Press.

Färdigh, M. 2013. What's the Use of a Free Media? The Role of Media in Curbing Corruption and Promoting Quality of Government. Gothenburg: Dep. Of Journalism, Media and Communication.

Gilley, B. 2009. The Right to Rule. How States Win and Lose Legitimacy. New York: Columbia University Press. 
Gjefsen, T. 2012. Sources of Regime Legitimacy. Quality of Government and Electoral Democracy. Oslo: Department of Political Science.

Holmberg, S. 2009. Perceptions of Corruption in Mass Publics. Gothenburg: The QoG Institute.

Holmberg, S., Weibull, L. and Oscarsson, H. 2011. Lycksalighetens ö. Gothenburg: The SOM Institute.

Holmberg, S. and Weibull, L. 2013. Förtroendet för sambällets institutioner. Utvecklingen i Sverige 19862012. Gothenburg: The SOM Institute.

Holmberg, S. and Rothstein, B. (Eds.) 2012. Good Government. The Relevance of Political Science. Cheltenham: Edward Elgar.

Inglehart, R. 1997. Modernization and Postmodernization: Cultural, Economic, and Political Change in 43 Countries. Princeton: Princeton University Press.

Kaufmann, D. 2004. Human Rights and Governance: The Empirical Challenge. Paper presented at the New York University School of Law, New York.

Kaufmann, D., Kraay, A. and Mastruzzi, M. 2010. The Worldwide Government Indicators: Methodology and Analytical Issues. Washington. World Bank.

Kittel, B. 2006. A Crazy Methodology? On the Limits of Macro-Quantitative Social Science Research. International Sociology. 21:5. Pp. 647-677.

Klingemann, H-D. (Eds.) 2009. The Comparative Study of Electoral Systems. Oxford: Oxford University Press.

Kumlin, Staffan (2004). The Personal and the Political: How Personal Welfare State Experiences Affect Political Trust and Ideology. New York: Palgrave-Macmillan. 
Lagos, M. 2003. Support for and Satisfaction with Democracy. International Journal of Public Opinion Research. 15:4. Pp. 471-87.

Linde, J. and Ekman, J. 2003. Satisfaction with Democracy: A Note on a Frequently Used Indicator in Comparative Politics. European Journal of Political Research 2003: 391-408.

Lipset, S.M. and Schneider, W. 1983. The Confidence Gap. New York: Wiley.

Luhman, N. 1989. Vertrauen. Ein Mechanismus der Reduktion Socialer Komplexität. Stuttgart: Fredinand Enke Verlag.

Magalhaes, P. 2013. Government Effectiveness and Support for Democracy. European Journal of Political Research (forthcoming).

Mayer, Roger C. James H. Davis and F. David Schoorman (1995) An Integrative Model of Organizational Trust The Academy of Management Review. 20:3. Pp. 709-734.

Misztal, Barbara A. (1996) Trust in Modern Societies: The Search for the Bases of Social Order. Cambridge. Polity Press.

Moberg, E. 2011. Statsvetenskap. Falun: Mobergs Publikationer.

Newton, K. and Norris, P. 2000. Confidence in Public Institutions: Faith, Culture, or Performance? In Pharr, S. and Putnam; R. (Eds.) Disaffected Democracies. Princeton: Princeton University Press.

Norris, P. 2000. A Virtuous Circle. Cambridge: Cambridge University Press.

Norris, P. 2008a Driving Democracy. Cambridge: Cambridge University Press. 
Norris, P. 2008b The Role of the Free Press in Promoting Democratization, Good Governance, and Human Development. In Harvey, M. (Ed.) Media Matters. Perspectives on Advancing Governance \& Development. Global Forum for Media Development.

Oscarsson, H., Dahlberg, S. and Martinsson, J. 2013. Medborgarpanelen/The Citizen Panel. Gothenburg: Department of Political Science, University of Gothenburg.

Ostrom, Elinor. (2005) Understanding Institutional Diversity. Princeton Paperbacks.

La Porta,.R. et al. 1999. The Quality of Government. Journal of Law, Economics and Organizations 1999: 222-79.

Pharr, S. and Putnam, R. (Eds.) 2000. Disaffected Democracies. Princeton: Princeton University Press.

Putnam, R. 1993. Making Democracy Work: Civic Traditions in Modern Italy. Princeton: Princeton University Press.

Putnam, R. 2001. Bowling Alone: The Collapse and Revival of American Community. London: Simon \& Schuster.

Rose-Ackerman, S., 2004: The Challenge of Poor Governance and Corruption,”

Copenhagen Consensus Challenge Paper, - draft, February 20.

Rothstein, B. 1998. Just Institutions Matter: The Moral and Political Logic of the Universal Welfare State. Cambridge: Cambridge University Press.

Rothstein, B. and Stolle, D. 2008. The State and Social Capital: An Institutional Theory of Generalized Trust. Comparative Politics 2008; 441-59. 
Rothstein, B. and Teorell, J. 2012. Defining and Measuring Quality of Government. In Holmberg, S. and Rothstein, B. (Eds.) Good Government. The Relevance of Political Science. Cheltenham: Edward Elgar.

Schneier, B. 2012. Liars \& Outliers. Enabling the Trust that Society Needs to Thrive. Indianapolis: John Wiley.

Stahl G. K. and Sitkin S. B. (2004). Trust in mergers and acquisitions. Presented at the annual meeting at the Academy of Management. Washington. D.C.

Sussman, L.R. 2001. Press Freedom in Our Genes: A Human Need. Reston: World Press Freedom Committee.

Teorell, Jan, Nicholas Charron, Stefan Dahlberg, Sören Holmberg, Bo Rothstein, Petrus Sundin \& Richard Svensson. 2013. The Quality of Government Dataset, version 20Dec13. University of Gothenburg: The Quality of Government Institute, http://www.qog.pol.gu.se.

Trädgårdh, L. (Ed.) 2009. Tillit I det moderna Sverige. Stockholm: SNS förlag.

Tyler, Tom R. (2003) The Role of Procedural Justice and Legitimacy in Shaping Public Support for Policing. Law \& Society Review. 37: 3.

Uslaner, Erik M. 2002. The Moral Foundations of Trust. Cambridge: Cambridge University Press.

Uslaner, E.H. 2008. Corruption, Inequality, and the Rule of Law: The Bulging Pocket Makes the Easy Life. Cambridge: Cambridge University Press.

Weibull. L., Oscarsson, H. and Bergström, A. 2013. Vägskäl. Gothenburg: The SOM Institute

World Bank 2013. World Development Indicators. Washington DC: The World Bank Group, Published Online, January 24, 2013. 
